\title{
World Heritage: exploring the tension between the national and the 'universal'
}

\author{
Tijana Rakic \\ Donna Chambers \\ Napier University
}

Contact author: Tijana Rakic, tijana224@gmail.com

Postal addresses: Ms Tijana Rakic, School of Marketing, Tourism and Languages, Napier University, Craiglockhart Campus, 219 Colinton Road, EH14 1DJ, Edinburgh,

UK; Dr Donna Chambers, School of Marketing, Tourism and Languages, Napier University, Craiglockhart Campus, 219 Colinton Road, EH14 1DJ, Edinburgh, UK

\begin{abstract}
:
The complex issues of conservation, politics, tourism management and ownership have emerged as critical issues within the World Heritage debate and specifically within heritage tourism research. Within this context, this article focuses on issues of ownership and belonging and argues that there exists a link between the conceptual inconsistencies inherent in the World Heritage idea and the tensions between the national and the 'universal' evident at a number of World Heritage Sites. That is, heritage sites which are deemed to be of 'outstanding universal value' and are bestowed with the World Heritage accolade are consequently no longer expected to be perceived as symbols of particular national identities, but as heritage belonging to all humankind. This, of course, provokes a series of debates over the issues of ownership and belonging of such heritage, namely between the national and the 'universal' suggesting that it is possible to perceive World Heritage as synonymous with contested heritage. The paper explores these issues of ownership and focuses on the Acropolis, symbol of the World Heritage idea (UNESCO, 2006d) as a case study utilising an exploratory semiotic analysis of the promotional material released by the Greek National Tourism Organisation over the last five years.
\end{abstract}

Keywords: World Heritage, tourism, Acropolis, ownership, semiotics 


\section{Introduction}

World Heritage has recently become one of the major topics within heritage tourism research and this is so whether this research is dealing with tourism management and marketing issues (i.e. Hall and Piggin, 2003; Leask and Fyall, 2006; Shackley, 2001), is exploring policy and conservation issues (i.e. Harrison and Hitchock, 2005; Kavoura, 2001; Rakic and Leask, 2006; van der Aa, 2005) or is dealing with tourists' understanding of the significance of the World Heritage Site status (i.e. Moscardo et al, 2001; Smith, 2002). The reason for this growth in scholarly research is that World Heritage Site status has become a 'highly appreciated accolade' (Smith, 2002:137) in the tourism world and has also emerged as one of the major promotional tools for site managers (Hall and Piggin, 2003; Rakic and Leask, 2006; van der Aa, 2006). Indeed, this is of such importance to the tourism industry that marketing strategy commentators are now speaking of 'the future markets for World Heritage Sites' (Fyall and Rakic, 2006).

The World Heritage Convention was adopted by UNESCO in 1972 and became effective on 17 December 1975. Since then, States Parties, as signatories to the Convention, are obliged to identify, protect and preserve heritage of 'outstanding universal value' (UNESCO, 2006b). Currently, the prestigious World Heritage List includes 812 heritage sites (UNESCO, 2006d). Importantly, the World Heritage idea, the idea of creating an international movement for the protection of heritage was in fact born just after the First World War (UNESCO, 2006a) and was underpinned by modernistic values. Fifty years later it was being used as a tool for the conservation of heritage sites of 'outstanding universal value' (UNESCO, 2006b), although today, in what can be described as a postmodern tourism industry, World Heritage Site status is being used as an accreditation scheme for heritage tourism attractions.

Since its creation and irrespective of a number of problematics that emerged, the List managed to achieve significant global success and World Heritage Site status is now perceived as a prestigious acknowledgement of the quality and uniqueness of heritage sites. In addition, both the List and the World Heritage Site status became a reference point for the cultural/heritage tourist, an equivalent of a constantly updated list of 'authentic' heritage sites worth visiting. For their part, countries or States Parties to the 
Convention, are competing to get sites listed (Rakic, 2005). Indeed, World Heritage Site status has become a measure of quality assurance, a trademark and an 'authenticity stamp' for the heritage tourist and an arena for the presentation of prestigious national heritage, integral to the nation building projects of States Parties. In this sense the concept of World Heritage has drifted away from its original intention. That is, having begun as a system of identifying, protecting and preserving heritage of 'outstanding universal value', which represent and belong to all humankind, it has essentially become an accreditation scheme for heritage sites, used either to serve the purposes of the tourism industry or for the purposes of nation building.

As indicated, the original idea of World Heritage, born just after the First World War, had a particular emphasis on the modernistic notions of heritage as having universality and universal values which required protection and conservation for the benefit of future generations of humankind. Since the adoption of the Convention in 1972 until today, in an era many would define as postmodern, the World Heritage concept has been celebrated, honoured and used for the purposes of not only conservation but also tourism. Importantly, it was in this period that its marketing potential was discovered by the tourism industry and the concept of World Heritage has consequently become more important for the purposes of tourism promotion than conservation. World Heritage Sites, along with other heritage sites, are increasingly being commercialised, commodified and used for postmodern forms of leisure (Harvey, 2001) such as heritage and cultural tourism (Hannabuss, 1999).

Using the Acropolis, a World Heritage Site and a symbol of the World Heritage idea (UNESCO, 2006d) as a case study, this paper argues that it is not only the widespread commercialisation through tourism that has caused the original idea of World Heritage to drift away from its original intention, but also the conceptual inconsistencies that are inherent in the very idea of World Heritage.

\section{The World Heritage Concept: tensions between the national and the 'universal'}

The concept of World Heritage is based on the idea of 'outstanding universal value' where sites are perceived as symbols of the 'common identity of humankind.' Not only is this 
inherently paradoxical, but the idea ignores the strong link between heritage and national identity. That is, the concept of heritage, similar to the concept of nation, is a modern construct and as such strongly linked with the project of nation building (Chambers, 2005; Graham, 2002; Hewison, 1987; Walsh, 1999). This indicates that all heritage is essentially about the construction of particular localised identities rather than 'universal identities' (i.e. identities shared by humankind). It is in this sense that the World Heritage idea carries a conceptual inconsistency which has arguably resulted in the tensions between the national and the 'universal' at a number of World Heritage Sites.

Several previous studies have examined these particular tensions, some in a broad context and others in a more site specific sense. Ashworth (1997:12) in his essay titled "Is there a World Heritage?" discusses "the need to believe in the existence of World Heritage as the common property of all humankind'. However, later on in the same work he claims that 'if all heritage by being someone's, must disinherit someone else, then a world heritage is not a happy summation of local and national heritage, but rather a denial of them'. He then goes on to discuss how these problems extend to the questions of ownership, specifically in the context of whether World Heritage is seen as nationally or ecumenically owned. Although mentioning that UNESCO is actually reinforcing the superiority of national ownership of World Heritage Sites, Ashworth nevertheless argues that until ownership of these sites is 'collectivised on a world scale, rather than nationalised or localised, then [World] heritage will be more a cause of national and local conflict that of global reconciliation' (ibid: 12.). In other words, Ashworth (1997) questions the very existence of World Heritage as it was intended by UNESCO in 1972 when the World Heritage Convention was adopted.

Further verifying the arguments raised by Ashworth in 1997 is the commentary of Ashworth and van der Aa in 2002 surrounding the destruction of the Buddhist statues at Bayman, Afghanistan by the Taliban, where they claim that 'the idea of world heritage, and its manifestation in international tourism, may conflict with heritage used for local and national purposes' (ibid: 447). Indeed, as noted by Ashworth and van der Aa (2002), although UNESCO promotes the existence and the need for humanity to have a 'World' [category of] heritage, where such heritage is promoted as 'belonging' to all humankind, 
UNESCO itself seems to hold a contradictory position with a number of its policies favouring the rights of national ownership. World Heritage can thus be seen as synonymous to 'contested heritage', with a great number of interested parties ranging from local, regional, national and international stakeholders exercising conflicting claims and rights of ownership, use and interpretation over a single heritage site.

However, there are a number of claims that heritage can exist on several levels and have multiple roles. Timothy (1997) argued that heritage tourism attractions and experiences exist on personal, local, national and world levels. It seems that it is not only members of the tourism academia or UNESCO that share this opinion, but also professional archaeologists and physical anthropologists, who in Skeates's (2000: 20) view 'accept the overlapping concepts of national and universal ownership [of UNESCO's World Heritage]'.

Similar contradictions stemming from the conceptual inconsistencies of the World Heritage idea seem to be reflected in the marketing world where some States Parties advertise their World Heritage Sites and emphasise their status (i.e. Spain with its 2006 "Smile you are in Spain" campaign (Spanish Tourist Office, 2006) promoting its World Heritage cities) while others choose to promote their sites but fail to ever mention their World Heritage Site status (i.e. the promotional material released by the Greek National Tourism Organisation over the last 5 years).

\section{Methodology}

In order to explicate the issues surrounding the national versus 'universal' debate in World Heritage, this paper examined the case study of the Acropolis in Athens, Greece, since the Acropolis is said to be the symbol of the World Heritage idea (UNESCO, 2006d) and at the same time is seen as a key symbol of Greekness (Yalouri, 2001). In order to do so, the paper will first review the existing literature on the Acropolis which discusses some of the national versus 'universal' debate and will then focus on the findings of an exploratory semiotic analysis of official representations of the Acropolis within the promotional texts and images released by the Greek National Tourism Organisation (GNTO) over the last five years. This will provide a brief insight into the extent to which 
the tensions between the national and the 'universal' are manifested within official representations of the Acropolis, one of the key World Heritage Sites.

Semiotics, or the [modern] study of signs which seeks to uncover the 'system of signs' and the 'deep structure' of meaning, was founded by the linguist Ferdinand du Saussure (1857-1913) and the philosopher Charles Sanders Peirce (1839-1914) (Echtner, 1999: 47). Despite the fact that the two founders, Saussure and Peirce, had significantly different approaches due to their background, semiotics has developed as a single approach constituted of various methods of analysis. Much of the later work in semiotics, particularly in literary theory and philosophy, was done by Roland Barthes (see for example Barthes 1977; 1988; and 1993). However, further influential contributions were also made by Charles W. Morris, Claude Lévi-Strauss, Julia Kristeva, Umberto Eco, Jean Baudrillard and others. In tourism studies, the semiotic approach has been utilised to address various research questions in a number of studies. Namely, following the article published by Culler in 1981 which looked at tourism and semiotics, Uzzell (1984) used semiotics in his analysis of tourism marketing, Cohen (1989) in his analysis of the hill tribe trekking promotional material in Northern Thailand and Bhattacharyya (1997) in her analysis of a Lonely Planet guide book to India.

With particular reference to the potential methods and modes of utilisation of the semiotic approach in tourism research, Echtner (1999) proposes six stages of analysis. She does indicate however that these stages are in no way prescriptive as semiotic analysis 'allows considerable analytic freedom and creativity in terms of methods and procedures' (1999: 55). As such these stages were adapted to fit this particular research question. First the data set to be analysed was identified and collected, namely the promotional material released by the Greek National Tourism Organisation for the years 2002, 2003, 2004, 2005 and 2006. Second, specific units such as the promotional material containing reference to the Acropolis were selected for analysis. Third, the consistency of occurrence of certain elements such as phrases or images which pointed to the tensions between the national and the 'universal' were identified. Finally, underlying or 'deep' meanings were extracted and debated. 


\section{The Athenian Acropolis: whom does it belong to?}

To whom the Athenian Acropolis belongs, whom it represents and whose identity it symbolises is a discussion dating back to 1802 when Lord Elgin, the then British ambassador to the declining Ottoman Empire, had removed twelve statues from the pediments, fifty six slabs and fifteen metopes from the frieze of the Parthenon (Kondaratos, 1994; Hitchens 1997) and transported them to Britain. In 1816 he sold them to the British Museum in London where they still remain. This event not only provoked a series of discussions over the ownership of the Parthenon Marbles, also known as 'Elgin Marbles', but has resulted in fierce international political and legal battles (see Hellenic Ministry of Culture, 2000; The British Museum, 2006a; 2006b; 2006c; 2006d; Hitchens, 1997; The British Committee for the Restitution of Parthenon Marbles, 2002).

However, the rise of the Acropolis as both the key symbol of Greek national identity and a monument of 'universal' significance was a gradual process. Despite the growth of humanistic studies in the $15^{\text {th }}$ and the $16^{\text {th }}$ century, the Acropolis, the sacred rock of Athens and the physical remains of Greek antiquity seem to have been of little importance to European scholars at the time (Athanassopoulou, 2001). Nonetheless, that was soon to change. According to Travlou (2001: 44-45), the first travellers to Greece in the $16^{\text {th }}$ and the $17^{\text {th }}$ century were mainly 'English and French botanists, amateur archaeologists, or merchants', in the $17^{\text {th }}$ and the early $18^{\text {th }}$ century there was a growth of visiting 'scholars, poets, members of the Society of the Dilettanti and young aristocrats in their Grand Tour' while the $19^{\text {th }}$ century saw 'the most influential of all travellers', visiting Greece, namely writers such as 'Lord Byron, Shelley, Chateaubriand, Flaubert and Lamartine'.

While the Ottoman Empire was in its decline, the fame of the Acropolis was spreading in Europe. This was partly due to the Parthenon (or 'Elgin') Marbles being exhibited in Britain provoking the increasing interest of scholars into the physical remains of Ancient Greece, and partly due to the fact that many travellers to Athens were classically educated, which 'heightened their sense of the Acropolis as a holy place' (Leontis, 1995: 42). One of the most commonly quoted travellers to Athens, Lord Byron a British 
Philhellene, who was actively propagating the 'Greek cause' wrote a poem in 1812 titled Childe Harold's Pilgrimage, which was to become one of the most popular poems at the time and which helped establish the Parthenon as a symbol of Greek National Identity (Skeates, 2000).

The rise of the Acropolis as a 'dual' symbol, of both Greekness and the Western world, was greatly influenced by Philhellenism, Classical Scholarship and the travellers to Greece. During the process of the making of the Modern Greek state, the Acropolis became the ultimate symbol of Greekness now perceived as the embodiment of the Greek nation (Yalouri, 2001). However, once the Greek state adopted the World Heritage Convention in 1981, the Acropolis, the cradle of democracy, was one of the first Greek heritage sites to be listed on the World Heritage List. Although it was with this act that its 'universal' significance and belonging was recognised not only by the Greek State but also by UNESCO, this did not result in international reconciliation over the issue of the legal ownership of the Parthenon Marbles or in recognition that the Acropolis 'belongs' both to the world and to the Greek nation. Instead, the Acropolis continues to be a contested heritage site, torn between the national and the 'universal'.

A study by Eleana Yalouri, published in 2001 which examined the significance of the Acropolis as a symbol of Greek national identity found that the Acropolis, a World Heritage Site is, similar to the Greek flag, a key concept of the Greek nation over which contestations about national ownership are constantly emerging. In looking at these dual ownership claims, the 'global' and the 'local', Yalouri states that:

"...the Athenian Acropolis, 'the corner stone of the Classical Greek era', in becoming a
'world monument' also became the national monument of Greece par excellence. The
question is how these two local/national and global meanings of the same monument can
co-exist and interrelate and how Greeks cope with this double-faceted aspect of their
heritage, especially in an era which on the one hand promotes the idea of global
community and on the other encourages national difference."

(Yalouri, 2001:8)

Another study, undertaken by Androniki Kavoura (2001) which investigated the state policy for the presentation of Greek National Heritage focused in particular at the cultural World Heritage Sites. Kavoura interestingly found that the two Greek governmental bodies, the Greek Archaeological Council and the Greek Ministry of Culture, which are 
also the bodies determining sites to be nominated for inclusion on the World Heritage List, perceive the List as an arena for the promotion of Greek national identity represented through a selection of Classical and Byzantine sites, rather than a representation of sites of 'outstanding universal value' located in Greece. Thus, perceiving the World Heritage Sites belonging to the nation rather that the world.

This point is supported in the exploratory semiotic analysis of the representations of the Acropolis within the promotional material of the GNTO over the last five years (20022006). Specifically, within the current GNTO website (2006) although the Acropolis is featured as the most dominant image, its World Heritage Site status fails to be mentioned, as is the case with the remainder of the promotional material. By constantly omitting to mention the World Heritage Status of the Acropolis in their promotional material, the GNTO, accidentally or intentionally, presents the Acropolis as belonging to the Greek nation, exhibited both for the Greek and foreign visitors.

For example the 2005 Athens and Attica guide states:

The Acropolis is the symbol of Athens, the sacred rock, linking the fabulous ancient civilisation with the modern city. The monuments on the Sacred Rock date back to the prehistoric era and antiquity. The grandeur and the beauty of the Sacred Rock attract both Greek and foreign visitors.

(GNTO, 2005)

When this text is examined carefully, it is possible to see that the reader is told that the Acropolis is the symbol of Athens, meaning that it represents the Athenians in particular and the Greeks in general. In other words the Acropolis is a signifier of Athenian and Greek identity (the signified). Its 'universal' or global significance as the cradle of democracy as well as its World Heritage Site Status are omitted. Occluding such important details about the Acropolis suggests that the Acropolis is above all a symbol of Athenian and Greek identity rather than having a universal application. Further on, the reader is told that the Acropolis is a sacred rock, but what the reader is not explicitly told is whose sacred rock it is. However, as this statement comes right after the text which establishes the fact that the Acropolis is the symbol of Athens it inclines the reader to believe that the Acropolis is a sacred rock primarily for the Athenians and, by extension, for the Greeks. Indeed the use of the word sacred adds a religious or spiritual dimension 
to the Acropolis which means sacrosanct or something beyond human understanding and questioning, while the use of the word rock connotes stability. So that, for the Athenians and for the Greeks, the Acropolis is represented in this text as an unquestionable and immutable component of their national identity. The rest of the world is not referred to until the part in the text which states that the monument's beauty and grandeur attract 'both Greek and foreign visitors'. An interpretation of this section of the text is that the Acropolis attracts both the Greek and the foreign visitors, where for all of them it is a 'unique experience': It is unique for the foreign visitors who can admire the grandeur of the monument and it is unique for the Greeks for whom not only is it grand, but also sacred, and a visit would be akin to a pilgrimage. The Acropolis thus signifies different things to different people and it cannot therefore have a universal meaning.

In the promotional campaign for the years 2002 and 2003, GNTO used the concept of 'Greek roots' in a linguistic sense where the theme of this campaign was dominated by international words of Greek origin such as antithesis, architecture, athletic, echo, energy, epic, Eros, euphoria, gastronomy, gymnasium, horizon, logic, magnetism, mathematics, phenomenon, symposium, tactics and theatre. The Acropolis is depicted under the word 'Architecture', and here the text states:

Architecture. Word of Greek Origin. It connects science and art. Greece owns more shining architectural points of glance than any other European country. Simply come and discover these!

(GNTO, 2002: translated from German, italics added)

This is an explicit reference to the fact that the Acropolis is owned by Greece and thus not by the world, again highlighting its national rather than universal context and ownership.

In the years 2005 and 2006, within the campaign 'live your myth in Greece' (GNTO, 2006) and its print advertisements, the Acropolis, or to be more precise the Parthenon, appears as a subliminal image, depicting a dream like state and the 'mythical' experience of Greece and its ancient world through a visit to Greece and the Acropolis. In the videos released under the same campaign, the image of either the Acropolis or the Parthenon appears regularly and although not a subliminal image anymore, the Acropolis is still depicted as a dream like, mythical place. For example in the video 'history' released in 
2005, Elena Paparizou (2005 Eurovision Song Contest Winner) takes her viewers on a tour of Greece and says:

...Welcome to a land of mythical dimensions and great sightseeing. Welcome to Greece...[followed by a postcard like video slide show where the Acropolis features first]...come to Greece, live your own myth and relive the history of the mythical civilisation....

(GNTO, 2006)

What is particularly interesting to notice is that although the Acropolis is said to be a contested heritage site torn between its 'global fame' and 'local claim' (Yalouri, 2001) and especially taking into consideration the widely known international legal battle over the ownership of the Parthenon or 'Elgin' marbles, these evident tensions between the national and the 'universal' are not leaving an obvious mark in the promotional material of the GNTO. This absence of an explicit tension in the promotional material might, on the other hand, be perfectly understandable, since an obvious reference to the existing conflict between the national and the 'universal' in the case of Acropolis could have an adverse effect on some of the potential visitors to Greece, who might perceive such conflict as politically incorrect. However, what is significant for the discussion in this paper is not what is being obviously put forward, but what is omitted by the GNTO in their promotional material. Indeed, the 2004 promotional campaign, in the light of the Olympics which were to be held in Athens that year, focused on 'records', such as 'the European record for the widest smile', '... world record for standing in still amazement', 'fastest time for being transported back to the ancient world' and 'all-time European for the most sunshine' (GNTO, 2004) and despite the reference made to visitors to Greece 'being transported back to the ancient world' by visiting Athens, neither the Acropolis, nor its World Heritage Site status were mentioned.

Several questions emerge from this exploratory analysis: Why is it that in the 2004 Olympic campaign the Acropolis is not mentioned as a key heritage site and attraction in Athens? Why is it that in the other campaigns, which as noted earlier often use the Acropolis in their promotional material, there is a failure to mention the World Heritage Site status of this monument? Why is it that within the promotional materials of the GNTO the World Heritage Site status of the Acropolis is hinted at only once in a document of the Ministry of Culture accessible through the GNTO website (GNTO, 2006) which features a small World Heritage Site symbol recognisable only to those who are 
familiar with this symbol? Certainly a plausible answer to these questions is that the Acropolis, despite its World Heritage Site Status, is perceived by the GNTO, the official tourism promotional body of Greece, as belonging to, and representing the Greek nation rather than the world.

\section{Conclusion}

This study discussed the tension that exists between the national and 'universal' within the idea of World Heritage and suggested that this tension stems from the conceptual inconsistencies inherent in the very idea of World Heritage. It was argued that this tension is manifested at particular World Heritage sites where issues of national versus 'universal' ownership become problematic. Using the Acropolis as a case study, the research, through an exploratory semiotic analysis of promotional material published by the GNTO over the last five years, demonstrated that while the Acropolis is a World Heritage Site and thus of 'universal' value and significance, it is, paradoxically, perceived primarily as a symbol of Greek national identity with little reference to its 'universal' status.

However, the case study does have its limitations. The first is that in seeking to demonstrate the tensions between the national and the 'universal' apparent in the official representations of the Acropolis, it focused only on the promotional material released by the GNTO over the last five years. While this does go further than traditional semiotic analyses that tend to be synchronous in nature, an analysis of a longer historical period might have gleaned further insights into this issue. Second, it did not examine other representations of the Acropolis in unofficial tourism publications such as guidebooks which might have been useful for comparative purposes. Third, it did not address the interpretant or the interpretation of the Acropolis by local and international visitors to the site. These limitations also constitute potential areas of further research.

In terms of the conceptual inconsistencies of the World Heritage idea, although these have been explored by the members of the academic community in the past, this remains to be an under researched area with more contributions needing to be made in order to shed further light on what seems to be emerging as a crucial issue within World Heritage 
research. Such research would prove vital not only for the academic community, but also for the members of UNESCO, the IUCN and ICOMOS. Indeed, as the World Heritage List and the processes of inscription, conservation and management of these properties continue to be problematic, further research is needed which would investigate whether these problems result from. commercialisation, tourism, nomination politics and conservation, or result from the conceptual inconsistencies in the idea of World Heritage manifested in the tensions between the national and the 'universal' evident at a number of World Heritage Sites, including the Acropolis - 'the symbol of the world heritage idea' (UNESCO, 2006d).

\section{References}

Ashworth, G. J. (1997) Is there a World Heritage? Urban Age, 4, (4), 12.

Ashworth, G. J. and VAN DER AA, B. J. M. (2002) Bayman: Whose Heritage Was It and What Should We Do About it? Current Issues in Tourism, 5, (5), 447-457.

Athanassopoulou, E. F. (2001) An "Ancient" Landscape: European Ideals, Archaeology, and Nation Building in Early Modern Greece. Journal of Modern Greek Studies, 20, (2), 273-305.

Barthes, R. (1993) Mythologies. London: Random House.

Barthes, R. (1988) The semiotic challenge. New York: Hill and Wang.

Barthes, R. (1977) Elements of Semiology. New York: Hill and Wang.

Bhattacharyya, D. P. (1997) Mediating India: An analysis of a guidebook. Annals of Tourism Research, 24, (2), 371-389.

Chambers, D. (2005) Heritage and the Nation: an exploration of a discursive relationship. Tourism Analysis, 9, 241-254.

Culler, J. (1981) Semiotics of Tourism. American Journal of Semiotics, 1, 127-40.

Cohen, E. (1989) Primitive and remote: Hill tribe trekking in Thailand. Annals of Tourism Research, 16, (1), 30-61.

Echtner, C. M. (1999) The semiotic paradigm: implications for tourism research. Tourism Management, 20, 47-57.

Fyall, A. and Rakic, T. (2006) The Future Market for World Heritage Sites. In A. Leask and A. (Eds.) Managing World Heritage Sites. Oxford: Butterworth Heinemann. 
GNTO (2006), “Greek National Tourism Organisation's website”. Online documents at URL http://www.gnto.gr/?langID $=2$ [15 ${ }^{\text {th }}$ September 2006].

GNTO (2005) Athens - Attica: Greece, Athens: Greek National Tourism Organisation.

GNTO (2004) Campaign 2004: print advertisements. Athens: Greek National Tourism Organisation.

GNTO (2002) Architecture: print advertisement. Athens: Greek National Tourism Organisation.

Graham, B. (2002) Heritage as Knowledge: Capital or Culture? Urban Studies, 39, (5-6) 1003-10017.

Hall, C. M. and Piggin, R. (2003) World Heritage Sites: Managing the brand. In A. Fyall, B. Garrod and A. Leask (Eds.) Managing Visitor Attractions: New Directions. Oxford: Butterworth Heinemann.

Hannabuss, S. (1999) Postmodernism and the Heritage Experience. Library Management, 20, (5), 295-302.

Harrison, D. and Hitchock, M. (2005) The Politics of World Heritage: Negotiating Tourism and Conservation. Clevedon: Channel View Publications.

Harvey, D. C. (2001) Heritage Pasts and Heritage Presents: temporality, meaning and the scope of heritage studies. International Journal of Heritage Studies, 7, (4), 319-339.

Hellenic Ministry of Culture (2000) Memorandum on the Parthenon Marbles, submitted by the Government of Hellenic Republic to the House of Commons Select Committee of Culture, Media and Sport. Online documents at URL

http://www.culture.gr/6/68/682/memorandum.pdf $\left[20^{\text {th }}\right.$ August 2006].

Hewison, R. (1987) Heritage Industry. London: Methuen.

Hitchens, C. (1997) The Elgin Marbles: should they be returned to Greece? London:Verso.

Kavoura, A. (2001) State policy for the presentation of Greek national heritage: the case of the cultural world heritage sites. PhD Thesis. University of Stirling.

Kondaratos, S. (1994) The Parthenon as Cultural Ideal. In P. Turnikiotis (Eds) The Parthenon and its impact in modern times. Athens: Melissa.

Leask, A. and Fyall, A. (2006) Managing World Heritage Sites. Oxford: ButterworthHeinemann.

Leontis, A. (1995) Topographies of Hellenism. New York: Cornell University Press. 
Moscardo, G. Green, D. and Greenwood, T. (2001) How Great is the Great Barrier Reef! Tourists's Knowledge and Understanding of the World Heritage Status of the Great Barrier reef. Tourism Recreation Research, 26, 19-25.

Rakic, T. (2005) The Future of UNESCO's World Heritage List. Unpublished Thesis, Napier University.

Rakic, T. and Leask, A. (2006) World Heritage List: historical development, current status and future scenarios. Cutting Edge Research in Tourism Conference - New Directions Challenges and Applications Conference Proceedings. University of Surrey, 6-9th June.

Shackley, M. (2001) Sacred World Heritage Sites: Balancing Meaning With Management. Tourism Recreation Research, 26, (1), 5-10.

Skeates, R. (2000) Debating the Archaeological Heritage. Eastbourne: Duckworth.

Smith, M. K. (2002) A Critical Evaluation of the Global Accolade: the significance of World Heritage Site status for Maritime Greenwich. International Journal of Heritage Studies, 8, (2), 137-151.

Spanish Tourist Office (2006) "Smile. You are in Spain" Campaign. Online documents at URL http://www.spain.info/uk/TourSpain/Spain\%20Marks/?language=EN $\left[27^{\text {th }}\right.$

September 2006]

The British Committee for the restitution of Parthenon Marbles (2002) The Case for Return. Online documents at URL.

http://www.parthenonuk.com/the case for the _return.php $\left[14^{\text {th }} \mathrm{July} 2006\right]$.

The British Museum (2006a) The Parthenon Sculptures: Facts and Figures. Online documents at URL. http://www.thebritishmuseum.ac.uk/gr/debate.html [5 $5^{\text {th }}$ April 2006].

The British Museum (2006b) Why are the Parthenon Sculptures always in the news? Online documents at URL.

http://www.thebritishmuseum.ac.uk/newsroom/current2003/parsculpt.htm $\left[19^{\text {th }}\right.$ April 2006].

The British Museum (2006c) The Parthenon and its sculptures. Online documents at URL. http://www.thebritishmuseum.ac.uk/gr/grparth.html [19 ${ }^{\text {th }}$ April 2006].

The British Museum (2006d) Parthenon: Cleaning the Parthenon Sculptures. Online documents at URL.http://www.thebritishmuseum.ac.uk/gr/collo.html $\left[19^{\text {th }}\right.$ April 2006].

Timothy, D. J. (1997) Tourism and the personal heritage experience. Annals of Tourism Research, 24, (3), 751-754.

Travlou, P. S. (2001), Urban Tourism in Athens: Tourist Myths and Images, PhD Thesis. 
UNESCO (2006a) Brief History of World Heritage. Online documents at URL. http://whc.unesco.org/pg.cfm?cid=169 $\left[9^{\text {th }}\right.$ February 2006].

UNESCO (2006b) World Heritage Convention text. Online documents at URL. http://whc.unesco.org/pg.cfm?cid $=175\left[9^{\text {th }}\right.$ February 2006].

UNESCO (2006d) World Heritage List. Online documents at URL. http://whc.unesco.org/en/list $\left[9^{\text {th }}\right.$ February 2006].

Uzzel, D. (1984) An alternative structuralist approach to the psychology of tourism marketing. Annals of Tourism Research, 11, 79-99.

van der Aa, B. J. M. (2005) Preserving the heritage of humanity? Obtaining world heritage status and the impacts of listing. Groningen: University Library Groningen.

Walsh, K. (1992) The Representations of the Past: Museums and heritage in the postmodern world. London: Rutledge.

Yalouri, E. (2001) The Acropolis: global fame, local claim. Oxford: Berg. 